\title{
Correlation between thromboembolic score and anteroposterior diameter of left atrium and left ventricle ejection fraction in patients with atrial fibrillation
}

\author{
Snezana Lazic ${ }^{*}$, \\ Sanja Markovic², \\ Maja Sipic ${ }^{1}$, \\ Bratislav Lazic ${ }^{1}$ \\ Faculty of Medical Science \\ University of Priština, \\ Kosovska Mitrovica, Kosovo \\ ${ }^{2}$ Clinical Hospital Center \\ Pristina, Kosovo
}

KEYWORDS: atrial fibrillation, tromboembolic risk, transthoracic echocardiography. CITATION: Cardiol Croat. 2015;10(9-10):228. | DOI: http://dx.doi.org/10.15836/ccar.2015.228

*ADDRESS FOR CORRESPONDENCE: Snezana Lazic, Faculty of Medical Science University of Priština, Anri Dinan bb, Kosovska Mitrovica 38220, Kosovo. / Phone: +381-666060569 / E-mail: snezana_lazic@yahoo.com

ORCID: Snezana Lazic, http://orcid.org/0000-0001-6362-3713 • Sanja Markovic, http://orcid.org/0000-0003-2819-9018 Maja Sipic, http://orcid.org/0000-0003-4173-1224 • Bratislav Lazic, http://orcid.org/0000-0002-1186-140X

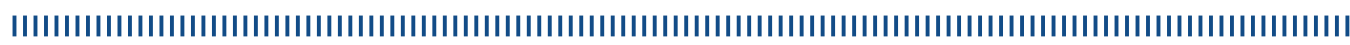
OBJECTIVES: It is considered that atrial fibrillation (AF) is present among $0.4 \%$ of adult population. $\mathrm{CHA}_{2} \mathrm{DS}_{2}$-VASc score is used for stratification of thromboembolic risk. Systolic heart failure has significant thrombogenic potential in atrial fibrillation. ${ }^{1}$ Data from the literature on causal relationship between enlarged left atrium and thromboembolic risk in patients with AF are controversial.

PATIENTS AND METHODS: The study analyzed 90 patients with atrial fibrillation. Exclusion criterion was AF in sepsis, acute myocarditis and pericarditis, in acute myocardial infarction, and postoperative AF. Methods used were standard 12-lead ECG, transthoracic echocardiogram and laboratory tests. The first group included 12 (13.3\%) patients with valvular AF, while the second group included 78 (86.7\%) patients with non-valvular AF.

RESULTS: Anteroposterior diameter of the left atrium was $55.6 \pm 11.5 \mathrm{~mm}$ vs. $46.3 \pm 6.2 \mathrm{~mm}$ in the second group; $\mathrm{p}<0.001$. Ejection fraction (EF, \%) was $37.1 \pm 10.1 \%$ in the first group vs. $43.0 \pm 11.6 \%$ in the second group; $\mathrm{p}=0.102$. $\mathrm{CHA}_{2} \mathrm{DS}_{2}$-VASc score was 4.0 (1.0-6.0) in the first group vs. 3.0 (0.0-7.0) in the second group; $\mathrm{p}=0.132$. The correlation between $\mathrm{CHA}_{2} \mathrm{DS}_{2}$-VASc score and anteroposterior diameter of the left atrium among all patients ( $\mathrm{n}=90)$ was not statistically significant $(\mathrm{r}=1.0 ; \mathrm{p}=0.346)$. Significant negative correlation was found between $\mathrm{CHA}_{2} \mathrm{DS}_{2}$-VASc score and EF among all patients $(\mathrm{r}=-0.420 ; \mathrm{p}<0.001)$.

CONCLUSIONS: In our study, the anteroposterior diameter of left atrium was not a determining factor of thromboembolic risk. However, with increase of $\mathrm{CHA}_{2} \mathrm{DS}_{2}$-VASc score, there was a reduction of EF which favors AF and increase in thromboembolic risk.
RECEIVED:

July 27, 2015

ACCEPTED:

September 17, 2015

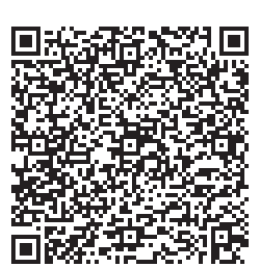

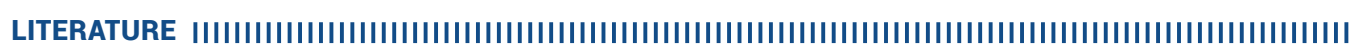

1. Colonna P. Echocardiography for embolic risk stratification in atrial fibrillation: improvement of CHA2DS2-VASc in the era of new oral anticoagulants. Rev Argent Cardiol 2013;81:102-6. DOI: http://dx.doi.org/10.7775/rac.v81.i2.2522 